\title{
Foods of Wild Horses, Deer, and Cattle in the Douglas Mountain Area, Colorado
}

\section{R. M. HANSEN, R. C. CLARK, AND W. LAWHORN}

Highlight: The foods of wild horses, cattle, and mule deer were determined from 10 widely separated areas in the Douglas Mountain Area, northwest of Craig, Colo. The major foods of wild horses and cattle were needlegrasses, wheatgrasses, and brome; those of mule deer were sagebrush and mountainmahogany. The dietary overlap for wild horses and deer was $1 \%$, cattle and deer $4 \%$, and wild horses and cattle was $77 \%$. Wild horses and cattle selected foods in a significantly similar order.

There is local concern for the recent increase of wild horses in northwestern Colorado in the Douglas Mountain Area. The major use of this area has been for livestock grazing and during the last 15 years there has been a steady decline in mule deer. The area is relatively free from human disturbances associated with mining, urban-industrial, and outdoor recreation influences. Hubbard and Hansen (1976) reported that the foods selected by wild horses and cattle in the Piceance Basin, Colo., were from 59 to $75 \%$ identical. Olsen and Hansen (1976) found that wild horse foods were $45 \%$ identical to cattle, $40 \%$ to elk

The authors are professor and graduate student, Range Science Department, Colorado State University, Fort Collins 80523 , and wild horse specialist, Bureau of Land Management, Meeker, Colorado 81641 .

This study was supported by funds from the Bureau of Land Management and by Colorado State University Experiment Station Project 1069.

Manuscript received March 10, 1976.
(Cervus canadensis), and $27 \%$ similar to domestic sheep in the Red Desert, Wyoming. There did not appear to be any serious dietary overlap between wild horses and mule deer (Odocoileus hemionus) in the Piceance Basin or with pronghorns (Antilocapra americana) in the Red Desert.

The main purpose of this study was to establish baseline information on the important foods of wild horses, livestock, and big game.

\section{Study Area}

Study areas were selected where aerial observations indicated there were bands of resident wild horses in the Douglas Mountain Area, approximately $100 \mathrm{~km}$ northwest of Craig, Moffat County, Colo. Ten areas used by one or more bands of wild horses were systematically located covering about $100 \mathrm{~km}^{2}$ between 5-Spring Draw (western) and Tepee Ranch Road (eastern). The vegetation at each area was not sampled but appeared to vary a great deal among areas. The vegetation types were primarily sagebrush-grass and pinyon-juniper with small patches of mountain brush; one area was within the ponderosa pine (Pinus ponderosa) type. Abundant trees and shrubs in the study area include pinyon pine (Pinus edulis), Rockymountain juniper (Juniperus scopulorum), and basin big sagebrush (Artemisia tridentata). Species of moderate occurrence include mountainmahogany (Cercocarpus montanus, $C$. ledifolius), Douglas rabbitbrush (Chrysothamnus viscidiflorus), wildbuckwheat (Eriogonum), broom snakeweed (Gutierrezia sarothrae), antelope bitterbrush (Purshia tridentata), and pricklypear (Opuntia fragilis and $O$. polycantha). Abundant grasses 


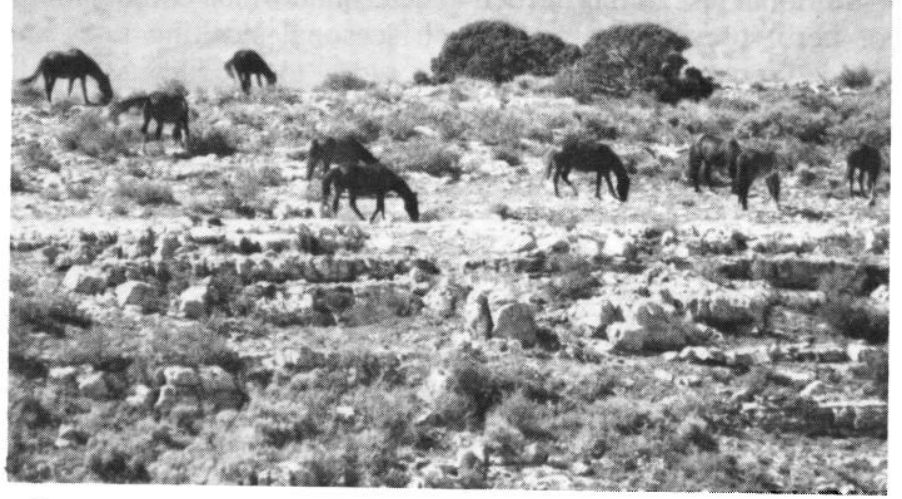

Horses on the range.

and grasslikes included western wheatgrass (Agropyron smithii), sedges (Carex spp.), needleandthread (Stipa comata), and green needlegrass $(S$. viridula $)$. Other grasses occurring in moderate amounts included bluebunch wheatgrass (Agropyron spicatum), prairie Junegrass (Koeleria cristata), Indian ricegrass (Oryzopsis hymenoides), and Sandberg bluegrass (Poa secunda). Abundant forbs on the study area were arrowleaf balsamroot (Balsamorhiza sagittata), stemless goldenweed (Haplopappus acaulis), and lupine (Lupinus spp.). Moderately occurring forbs include aster (Aster spp.), hairy goldenaster (Chrysopsis villosa), cryptantha (Cryptantha spp.), skyrocket gilia (Gilia aggregata), Nuttall goldenweed (Haplopappus nuttallii), Hoods phlox (Phlox hoodii), longleaf phlox (Phlox longifolia), and scarlet globemallow (Sphaeralcea coccinea).

Resident wild horses and six domestic horses used the Douglas Mountain area throughout the year. The wild horse population was estimated to be 304 in 1974 and 349 in 1975. Twenty additional domestic horses and 834 cattle are licenced by the Bureau of Land Management to graze the area during the spring, summer, and fall. Mule deer primarily use the area from May to November and then migrate to winter ranges.

Small bands of 5 to 10 wild horses are seen occasionally drinking at small reservoirs constructed to hold water for livestock or where there are natural springs or seeps. During the dry late summer it appears that all large herbivores are associated with water impoundments because drinking water is very limited by the low summer rainfall in this area.

\section{Methods}

The botanical composition of diets was determined by microscopic analyses of composited samples of fecal material. Fecal samples for the three herbivores were collected in the summer, 1975. Sample areas varied from 10 to 50 hectares. Collectors randomly subsampled undecomposed fecal droppings as they came upon them with no regard to season. A subsample of feces weighing about 2 grams was taken from each cow and horse defecation. Two pellets were taken from each pellet group of mule deer feces. A minimum of 50 of each herbivore's defecations were subsampled at each of the ten areas. The subsamples from an area were composited into a single sample for each of the herbivores. Although different herbivores may not simultaneously feed on an area, there is a need to estimate each herbivore species food habits when it feeds on an area.

A technician identified and quantified plant fragments in feces as described by Sparks and Malechek (1968). Fields on each microscope slide were viewed under a binocular microscope at $100 \times$ for identifiable plant fragments. Twenty slides were made per composited fecal sample and 20 fields were examined per slide, for a total of 400 fields per sample. The percentage of the classified plant fragments appears to approximate the percentage relative dry weights of food categories in the diet (Dearden et al. 1975; Hansen et al. 1973; Todd and Hansen, 1973)

Similarity of diets was calculated using Kulcyznski's mathematical formula (Oosting 1956). The similarity index represents the percentage of two diets that was identical. Spearman's rank correlation coefficient (Snedecor and Cochran 1973) was used to estimate differences between the orders of abundance of foods in two diets. Diversity indices were calculated by Shannon's formula (Hurtubia 1973). Common and scientific names of plants are those recommended by Beetle (1970).

\section{Results}

The diets of wild horses and cattle consisted mainly of grasses, including wheatgrass, brome, and needlegrass. Mule deer diets were almost entirely shrubs, with basin big sagebrush and mountainmahogany contributing the bulk of the diet (Table 1). The foods eaten by wild horses and cattle on the same areas showed a high degree of similarity, while the foods of mule deer showed little overlap with either of the other two herbivores (Table 2). Spearman's rank order statistic indicated a strong correlation between cattle and wild horse diets. Mule deer diets showed a negative correlation to wild horse and cattle diets (Table 2). The similarity indices and correlation coefficients show a strong potential for competition between wild horses and cattle, but little potential conflict between mule deer and the other two herbivores.

Table 1. Average composition (\%) of plants in diets of wild horses, cattle, and mule deer on ten areas in the Douglas Mountain Area, northwestern Colo., 1974.

\begin{tabular}{|c|c|c|c|}
\hline \multirow[b]{2}{*}{ Major forage types ${ }^{1}$} & \multicolumn{3}{|c|}{ Mean diets $(\% \pm \mathrm{SD})$} \\
\hline & Wild horses & Cattle & Mule deer \\
\hline Needlegrass (Stipa spp.) & $54 \pm 21$ & $50 \pm 19$ & $<1$ \\
\hline Wheatgrass (Agropyron spp.) & $17 \pm 9$ & $27 \pm 14$ & \\
\hline Brome (Bromus spp.) & $9 \pm 8$ & $7 \pm 4$ & $<1$ \\
\hline Danthonia (Danthonia sp.) & $6 \pm 5$ & $2 \pm 1$ & $<1$ \\
\hline Fescue (Festuca spp.) & $4 \pm 3$ & $2 \pm 3$ & $<1$ \\
\hline Sedges (Carex spp.) & $2 \pm 2$ & $3 \pm 2$ & $<1$ \\
\hline Common winterfat (Eurotia lanata) & $3 \pm 2$ & $<1$ & $<1$ \\
\hline Mountainmahogany (Cercocarpus spp.) & $<1$ & $3 \pm 3$ & $46 \pm 34$ \\
\hline Prairie Junegrass (Koeleria cristata) & $1 \pm 1$ & $2 \pm 2$ & \\
\hline Basin big sagebrush (Artemisia tridentata) & $<1$ & $1 \pm 2$ & $41 \pm 26$ \\
\hline Wildrye (Elymus sp.) & $1 \pm 1$ & $<1$ & - \\
\hline Antelope bitterbrush (Purshia tridentata) & $<1$ & $<1$ & $1 \pm 1$ \\
\hline Juniper (Juniperus spp.) & $<1$ & & $3 \pm 3$ \\
\hline Pinyon pine (Pinus edulis) & & $<1$ & $6 \pm 8$ \\
\hline Utah serviceberry (Amelanchier utahensis) & & $1 \pm 2$ & \\
\hline
\end{tabular}

Other foods $(<1 \%)$ in horse, cattle, and deer diets were Atriplex and Chrysothamnus; in horse and cattle diets, Hilaria, Oryzopsis hymenoides, Poa, Sporobolus, and Eriogon$\mathrm{um}$; in horse and deer diets, Mertensia and Lesquerella; in cattle and deer diets, Berberis and Phlox; in horse diets, Sitanion, Astragalus, Oxytropis, and Gutierrezia; in cattle diets, Lupinus and Sphaeralcea; in deer diets, Chrysopsis, Melilotus, Opuntia, Sarcobatus, Symphoricarpos, Valeriana, and an unidentified lichen.

Table 2. The average and standard deviation for dietary overlap for foods of herbivores and Spearman's rank correlation coefficients with the corresponding confidence values in the Douglas Mountain Area, Colo., 1974.

\begin{tabular}{lccc}
\hline \hline Relationship & $\begin{array}{c}\text { Percentage } \\
\text { similarity }\end{array}$ & $\begin{array}{c}\text { Spearman's } \\
\text { RHO values }\end{array}$ & $P$ values \\
\hline Cattle and deer & $4 \pm 4 \%$ & -.31 & $.14^{*}$ \\
Cattle and horses & $77 \pm 11 \%$ & +.62 & $>.01$ \\
Horses and deer & $1 \pm 1 \%$ & -.54 & $.05^{*}$ \\
\hline
\end{tabular}

*Not significantly correlated. 
Table 3. The "trophic diversities" for foods in diets of cattle, horses, and mule deer, Doughas Moumtain Area, Colo., 1974.

\begin{tabular}{lc}
\hline \hline Herbivore & Mean diversity index $( \pm$ SD $)$ \\
\hline Cattle & $1.41 \pm .39$ \\
Horse & $1.40 \pm .37$ \\
Deer $^{1}$ & $0.84 \pm .32$ \\
\hline
\end{tabular}

'Significantly lower than cattle and horse values $(P<.01)$.

The mean diversity of plants in wild horse and cattle diets were not significantly different, but each was significantly higher than that of mule deer (Table 3 ).

\section{Discussion}

Populations of the wild horses appear to be increasing at 10 $15 \%$ annually on the study area. Cook (1975) suggested that if wild horses are permitted to continue to increase on National Resource Lands in the West livestock grazing may need to be reduced. This study supports recent observations (Hansen 1976; Hubbard and Hansen 1976; Olsen and Hansen 1976) which suggest that wild horses and cattle feed primarily on the same plants. Mule deer food habits in this study and in previous reports (ibid) appear to be complementary rather than conflicting with diets of wild horses and cattle. This study suggests that wild horses and cattle feed very little on the principal foods of deer in the Douglas Mountain study area.

The proportions of the major foods of the three herbivores studied varied extensively among the 10 areas at Douglas Mountain. The percentages of needlegrass in wild horse and cattle diets ranged from $19-80 \%$ and $26-70 \%$, respectively. Wheatgrass, another important food of wild horses and cattle ranged from 7-34\% and $14-53 \%$, respectively. Basin big sagebrush and mountainmahogany ranged among areas from $1-77 \%$ and $0-97 \%$, respectively, in mule deer diets.

The average wild horse and cattle diets were comparable in percentage diet overlap in the Red Desert, Wyo. (Olsen and Hansen 1976) and Piceance Basin, Colo. (Hubbard and Hansen 1976). However, sedges made up over $25 \%$ of the wild horse and cattle diets in the Piceance Basin, but sedges averaged less than 5\% of either herbivore's diet at the Douglas Mountain and Red Desert study areas. Mule deer diets in the Douglas Mountain areas contained considerably less pinyon pine and juniper than was reported for areas in southern Colorado
(Hansen and Reid 1975) and in the Piceance Basin (Hubbard and Hansen 1976).

Efficient herbivore production, coupled with well-regulated use of range plants, may best be obtained by simultaneously grazing herbivores with different food habits (Sampson 1952; Cook 1954; Stoddart and Smith 1955; Committee of the Soil Conservation Workshops 1957; Tueller and Lesperance 1970). Additional research is needed to determine which combinations of herbivore species and which seasonal stocking rates are needed on particular vegetation types to produce a broad, efficient use of range plants.

\section{Literature Cited}

Beetle, A. A. 1970. Recommended plant names. Univ. Wyoming Agr. Exp. Sta. Res. J. Laramie. 31:1-24.

Committee of the Soil Conservation Workshops. 1957. Livestock and deer ratios for Texas range lands. Texas Agr. Exp. Sta. Misc. Pub. 221. 9 p.

Cook, C. W. 1954. Common use of summer range by sheep and cattle. J. Range Manage. 7:10-13.

Cook, C. W. 1975. Wild horses and burros: a new management problem. Rangeman's J. 2:19-21.

Dearden, B. L., R. E. Pegau, and R. M. Hansen. 1975. Precision of microhistological estimates of ruminant food habits. J. Wildl. Manage. 39: 402-407.

Hansen, R. M. 1976. Foods of free-roaming horses in southern New Mexico. J. Range Manage, 29:347.

Hansen, R. M., D. G. Peden, and R. W. Rice. 1973. Discerned fragments in feces indicates diet overlap. J. Range Manage. 26:103-105.

Hubbard, R. E., and R. M. Hansen. 1976. Diets of wild horses, cattle, and mule deer in the Piceance Basin, Colorado. J. Range Manage. 29:389-392.

Hutubia, J. 1973. Trophic diversity measurement in sympatric predatory species. Ecology 54:885-890.

Olsen, F. W., and R. M. Hansen. 1977. Food relations of wild free-roaming horses to livestock and big game, Red Desert, Wyoming. J. Range Manage. 30:17-20.

Sampson, A. W. 1952. Range management, principles and practices. John Wiley and Sons, Inc., New York. $570 \mathrm{p}$.

Snedecor, G. W., and W. G. Cochran. 1973. Statistical methods. Iowa State Univ. Press, Ames. 593 p.

Sparks, D. R., and J. C. Malechek. 1968. Estimating percentage dry weight in diets using a microscope technique. J. Range Manage. 21:264-265.

Stoddart, L. A., and A. D. Smith. 1955. Range management. McGraw-Hill Book Co., New York. 433 p.

Todd, J. W., and R. M. Hansen. 1973. Plant fragments in the feces of bighorns as indicators of food habits. J. Wildl. Manage. 38:363-366.

Tueller, P. T., and A. L. Lesperance. 1970. Competitive use of Nevada's range foragc by livestock and big game. Wildl. Soc. Cal.-Nev. Sect., Trans. 10:129-137. 


\section{THESIS: UNIVERSITY OF FLORIDA}

Short Duration Grazing in North Florida Flatwoods, by Barbara Lynn Felts. MS, School of Forest Resources and Conservation. 1976.

Two 1.5-ha replications of four grazing treatments were established in a north Florida flatwoods in a randomized block design. The treatments consisted of 1 week of grazing followed by rest periods of 2,4 , and 6 months. Two pastures remained ungrazed to serve as control plots. Annual forage production and disappearance trends, changes in standing biomass, forage composition, cattle utilization of available forage, and changes in soil bulk density and nutrient concentrations were used as response variables. The 1-year study reflected the immediate results of short duration grazing followed by a rest period.

Maximum annual forage production resulted from grazing followed by a 2 -month rest period. Annual production of wiregrass (Aristida stricta), a somewhat undesirable forage species, also was greatest on pastures rested 2 months. In contrast, creeping bluestem (Schizachyrium stolonifer), a highly desirable forage species, was greatest on pastures with a 4-month rest period. Maximum annual disappearance of total forage and wiregrass occurred on 2-month sites while maximum disappearance of creeping bluestem occurred on sites rested 4 months. Production/disappearance ratios suggest that grazable vegetation was increasing on control and 6-month pastures. All treatment pastures and vegetation categories had similar biomass curves, indicating similar growth cycles for grazed and ungrazed plots. The percent composition of legumes declined on all sites over time, with the largest decline occurring on 2-month sites. Utilization of particular forage species by cattle changed as a result of grazing treatment and forage availability and palatability. Soil bulk density increased as a result of length of rest and/or stocking rate, soil depth, and sampling date. Soil nutrient concentrations also changed, resulting from treatment effect, soil depth, sampling date, or a combination of the three. Overall, it appears that for more rapid range improvement, a 6-month rest period is most valuable. In order to achieve a better balance between forage quality and quantity for livestock on range which is in satisfactory condition, a 4-month rest period appcars most useful for understory management of north Florida flatwoods. 